\title{
English as medium of instruction and international posture: From the perspective of students
}

\author{
Dinçay Köksal $^{\text {a * (iD), Gülşah Tercan }}{ }^{\text {b (iD }}$ \\ ${ }^{a}$ Çanakkale Onsekiz Mart University, Department of Foreign Language Education, Çanakkale, 17000, Turkey \\ ${ }^{b}$ Pamukkale University, School of Foreign Languages, Denizli, 20000, Turkey
}

APA Citation:

Köksal, D., \& Tercan, G. (2019). English as medium of instruction and international posture: From the perspective of students. Journal of Language and Linguistic Studies, 15(1), 362-375.

Submission Date: 2018/03/26

Acceptance Date: 2018/12/03

\begin{abstract}
There is a significant effect of learners' perceptions on educational setting as the active participants of the learning process are learners. In this respect, revealing students' perceptions contributes to the improvement of learning and teaching. With this in mind, this study aimed to investigate English Language Teaching (ELT) students' International Posture and perceptions of the English as a Medium of Instruction (EMI) courses at a state university. In addition, the purpose of this study is to answer the research question related to the perceptions of students concerning EMI and IP by considering gender differences. The study was conducted with the students of ELT Department in the spring term of 2016 - 2017 academic year at a state university. A questionnaire and semistructured interviews were carried out with a view to establishing whether the concepts of International Posture and the students' perceptions of EMI are interrelated. The quantitative data obtained from the questionnaire were analyzed with the help of SPSS by means of descriptive statistics, Pearson's Correlation and Mann Whitney U test while content analysis was done for the qualitative data. The current study reported the perceptions of ELT students and revealed the differences and relations with regard to EMI and IP as well as male and female students. As the findings revealed, the students with high IP have positive attitudes towards EMI. Whereas, there is not a significant correlation between the perceptions of students related to EMI and IP. The findings of this research led to some suggestions for further studies.
\end{abstract}

C 2019 JLLS and the Authors - Published by JLLS.

Keywords: Attitude; English as a medium of instruction; English language teaching; international posture; learner perception

\section{Introduction}

English has become more integrated into the field of education day by day. Language policies of education institutions are determined by the English necessities of related countries. In this respect, English as Medium of Instruction has started to play a vital role in the education of universities in Turkey by virtue of realizing the importance of English and new language policies were enacted to boost English learning by Turkish Government. According to Karakas (2016), the Bologna process was started to establish new EMI universities in 2001, which aimed at increasing student and teacher mobility,

\footnotetext{
${ }^{*}$ Corresponding author.

E-mail address: koksal.dincay@gmail.com
} 
encouraging close relations with institutions abroad and creating a borderless education setting. In this way, the number international students has increased and academic faculties have occurred.

"The goal of second language (L2) and foreign language (FL) learning is to facilitate better communication and understanding between individuals who come from different cultural backgrounds and speak different languages" (Yashima, Zenuk-Nishide, Shimizu, 2004, p. 120). The purpose of learning a foreign language is closely related to the attitudes towards that language. If a learner holds positive attitudes towards the other language, he or she also has positive orientation for learning English (Karahan, 2007). The general attitude towards international community which is also called as International Posture (IP) affects motivation as well as predicting proficiency and second language communication confidence (Yashima, 2002).

Although EMI and IP were examined separately many time; the relationship between these two concepts was not investigated. Hereby, this research is going to be carried out to fill the methodological gap by analyzing the relationship between the perceptions related to EMI and IP as well as building on previous researches on the basis of gathered data. The data collected from the questionnaire and interview for the current research are going to be combined to shape the future of implementation of effective English teaching at ELT and different departments.

\subsection{Literature review}

\subsubsection{English as Medium of Instruction}

English as Medium of Instruction was described by Dearden (2014) as "the use of the English language to teach academic subjects in countries or jurisdictions where the first language (L1) of the majority of the population is not English" (p. 4). Similarly, Hellekjaer (2010) defined it as "non-language subjects taught in English" (p. 234). Although EMI is common for higher education, it has started to be used even in primary schools recently.

Usage of EMI in higher education is a controversial issue. Kirkpatrick (2011) asserted that the universities compete for attracting more attention from international students so that they can get students fees by offering more courses through English. Additionally, the increase in English medium education was resulted from the internationalization of higher education which leads to maintain AngloSaxon paradigm and rise their control over higher education. In contrast, some of the researchers in favor of EMI stated that EMI is a useful strategy to foster student mobility by means of internationalization of higher education which aims at developing foreign language and intercultural and international competences by implementing EMI (Corrales, Rey \& Escamilla, 2016). Hengsadeekul, Hengsadeekul, Koul and Kaewkuekool (2010) highlighted that since English is used as the most unrivalled language of global communication and business world as well as a tool of educational advancement; universities, policy makers and educator have been affected in deciding on the medium of instruction by social- economic pressure due to the impact of English.

Employing EMI courses grabbed the attention of many researchers recently and several studies have been carried out concerning the use of English as medium of instruction. The relationship of EMI with motivation (Kim, 2014), with academic achievement (Dafouz \& Camacho-Miñano, 2016; Dorasamy, 2012; Mlay, 2010; Shahzad, Sajjad, Ahmed, \& Asghar, 2013), with English proficiency, years of language study (Saegert, Scott, Perkins, \& Tucker, 1974) and effectiveness of EMI (earning motivation, learning anxiety, and learning achievement (Huang, 2015; Civan \& Coşkun, 2016) were the topics that were investigated by the researchers. Besides, concept of EMI was investigated by different researchers from different perspectives of participants. The following Table 1 shows the related studies related to EMI. 
Table 1. Studies related to EMI from different perspectives

\begin{tabular}{ll}
\hline Perspectives & Sources \\
\hline Teachers' perceptions related to EMI & $\begin{array}{l}\text { Başıbek, Dolmacı, Cengiz, Bür, Dilek \& Kara (2014); } \\
\text { Channa (2012); Jensen \& Thøgersen (2011); Su (2006); } \\
\text { Tilahun (2015); Zare-ee \& Gholami (2013) }\end{array}$
\end{tabular}

Students' perceptions related to EMI

Ismail, Mustafa, Muda, Abidin, Isa, Zakaria,... \& Rafee (2011); Kırkgöz, (2014); Kim, Kweon \& Kim, (2017); Kym \& Kym (2014); Rahmadani (2016); Tsui \& Ngo, (2017); Visconde (2006); Wu, (2006)

Both students and teachers' perceptions Corrales, Rey \& Escamilla (2016). Hilliard (2015); related to EMI Khan (2013)

The study of Rahmadani (2016) investigated students' perception of English as a Medium of Instruction (EMI) in English classroom and found out that most students had positive perception or agreed toward English as a medium of instruction so that they can improve their English skills and confidence to speak up, and understand more of English textbook or article and international culture. Similarly, students stated in the study of Wu (2006) that EMI was a helpful language policy which enables students to use English in the class and to learn it better by using in the class. However, in the study of Tsui and Ngo (2017), the students were worried about their academic results, motivation to learn and inclass discussion because of EMI courses. Likewise, Kim, et al. (2017) also analyzed the perceptions of students related to EMI and stated that most of the students preferred their mother tongue instruction and stated that EMI was not useful for their English ability.

\subsubsection{International Posture}

According to Collins (2013), the factors which are the issue of integrativeness and its hypothesized impact on L2 acquisition gave rise to the birth of IP as a construct since Gardner (1985) put emphasize on the concept of integrativevess; however, it was unable to account for language learning motivation where there is not L2 community. The concept of IP firstly uttered by Yashima (2002) as an "interest in foreign or international affairs, willingness to go overseas to stay or work, readiness to interact with intercultural partners, and, one hopes, openness or a non-ethnocentric attitude toward different cultures" (p. 57). IP which is more related to EFL contexts, tends to link oneself to the international community instead of a specific L2 group (Yashima, 2009). It is believed that IP affects learners' L2 learning and communication behaviour (Yashima, Zenuk-Nishide \& Shimizu, 2004).

In 2002, Yashima stated that IP includes four component dimensions as follows: (i) Intercultural Friendship Orientation, (ii) Interest in International/Vocational Activities, (iii) Interest in Foreign Affairs, and (iv) Approach Avoidance Tendency/Intergroup Approach; however, in 2009, she updated the components and added International News and Having Things to Communicate to the World instead of Intercultural Friendship Orientation and Interest in Foreign Affairs.

There are a few studies that is related to only IP (Binbaşıŏlu \& Sad, 2016; Courtney, 2008; Elwood \& Monoi, 2015; Siridetkoon, 2015); however the relationship between IP and some other issues were investigated more. Table 2 demonstrates the research studies. 
Table 2. The relationship between IP and other issues

\begin{tabular}{|c|c|}
\hline Topic & Source \\
\hline $\begin{array}{l}\text { Self-perceived communication competence (SPCC), IP and } \\
\text { motivation- Willingness to Communicate (WTC) }\end{array}$ & (Fallah \& Mashhady, 2014) \\
\hline Communicative language teaching (CLT), IP, WTC & (Aubrey, 2010) \\
\hline $\begin{array}{l}\text { Intrinsic-extrinsic motivation, L2 ideal selves, L2 ought-to selves, } \\
\text { IP, Can-Do and WTC }\end{array}$ & (Nishida, 2013) \\
\hline Proficiency, IP, L2 WTC, and other psychological constructs & (Matsuoka, 2005; Yashima, 2009) \\
\hline L2 learning and L2 communication variables in the, WTC, IP & (Yashima, 2002) \\
\hline IP, WTC and Second Language Communication & (Yashima, et al.,2004) \\
\hline WTC - Self-confidence - learners attitude (IP) - motivation & $\begin{array}{l}\text { (Hashimoto, 2002; Peng, 2007; } \\
\text { Şener, 2014) }\end{array}$ \\
\hline IP and WTC & $\begin{array}{l}\quad \text { (Asmalı, 2016; Aliakbari, } \\
\text { Kamangar, \& Khany, 2016; Collins, } \\
\text { 2013; Mahmoodi, Ghafoori \& Amini, } \\
\text { 2013; Piggin, 2010; Ulu, Weiwei, \& } \\
\text { Yu, 2015; Mystkowska-Wiertelak \& } \\
\text { Pietrzykowska, 2011) }\end{array}$ \\
\hline
\end{tabular}

The research of Asmalı (2016) examined the relationship among willingness to communicate and some variables such as students' motivation to learn English, their confidence for communication in English and their motivation to learn English. The findings suggested that these variables were found to be related to their WTC in English. Participants' attitude toward international community positively has an impact on their motivation to use and learn English as well. In contrast, in the study of Öz, Demirezen \& Pourfeiz (2015) which examined WTC, communication and affective factors, it was figured out that instrumental orientation and attitudes towards learning situation had no direct relationship with L2 WTC.

\subsection{Research Questions}

When the literature is searched, it can be seen that there is a gap related to the relationship between EMI and IP. Therefore, the present study seeks to answer the following questions in regard to the existing situation in the field:

1) What are the perceptions of students related to EMI and IP?

2) Is there a relationship between the perceptions of students related to EMI and IP?

3) Is there any significant difference between female and male students in terms of the perceptions concerning EMI and IP?

\section{Method}

Triangulation was used to gain more comprehensive understanding of the research problem by combining both quantitative and qualitative research methodologies. The purpose of triangulation is to increase the validity, reliability and the comprehensiveness of the study (Munhall \& Oiler, 2001; Lauri, 
2011). The data collection was achieved through (a) a questionnaire with students (b) interview with students studying at ELT Department currently. According to Nunan and Bailey (2009), combining questionnaire and interview data gives more reliable and rich data, which cause triangulation. As Wisdom and Creswell (2013) expressed, the advantages of using mixed methods in a study are indicating participants' point of view, enhancing scholarly interaction, gathering rich data, and comparing quantitative and qualitative data.

\subsection{Participants}

The context of the present research was a state university. The study was conducted at English Language Teaching Department which has EMI courses in the spring term of 2016-2017 academic year. A total of 58 ELT students between eighteen and twenty four age range (36 female, 22 male) who are studying in the third and fourth year of their departments voluntarily participated in the study. For the qualitative data, 3 students were interviewed. Purposeful sampling was found to be the most appropriate method with the aim of the research because purposeful sampling is "the careful and intentional selection of subjects for a study based on specified characteristics" (Macnee \& McCabe, 2008, p. 124). Third and fourth grade students from ELT Department were selected on purpose in order to collect the data since they are mature enough to express their perceptions and their awareness level is supposed to be higher than younger students.

\subsection{Instruments}

The data collection tools of the study were a questionnaire and semi-structured interview. The questionnaire includes three parts. In the first part, the participants' demographic information was collected. The participants were asked to respond to the items on their age, gender, and department. In the second part, the Questionnaire on Student Perceptions of English Medium Instruction (QSPEMI) developed by Huang (2015) was used. The questionnaire includes 25 six-point Likert scale items (" $1=$ strongly disagree" to " $5=$ strongly agree"), questions items, asking the participants' perceptions in terms of motivation, learning difficulties, and learning achievements in EMI courses. Cronbach's Alpha value of the questionnaire was .86 .

In the third part, International Posture questionnaire by Yashima (2009) was employed to collect the data. The questionnaire consists of 20 statements on five-point Likert scale. Intergroup ApproachAvoidance Tendency (6 items, Cronbach's Alpha $=.80$ ), Interest in International Vocation or Activities (6 items, Cronbach's Alpha = .79), International News (4 items, Cronbach's Alpha $=.76)$, and Having Things to Communicate to the World (4 items, Cronbach's Alpha $=.78$ ) are aimed to be measured.

After the second data collection tool, an interview was conducted with 3 students from the same department. The questions of the interview were related to the perceptions of EMI and IP. The aims of the interview was to gain a deeper understanding of students' perceptions.

\subsection{Data collection and analysis}

Employing a mix method design to answer research questions of the study, the questionnaire was administered to ELT students by giving sufficient time for completing the task. It was stated that their participation was voluntary and their answers would be used only for academic purposes. The consent forms were signed and the research was carried out. . The implementation lasted for almost 30 minutes, and the researcher actively took part in the data collection process in case of explanation related to the items.

The main data sources of this study are students studying at ELT Department. The data were collected through a questionnaire and interview. While the quantitative data were analyzed through descriptive 
statistics, Pearson's correlation and Mann Whitney U test, the qualitative data were examined, which was done by the researcher and her colleagues to reach inter-rater reliability. The interviews which lasted approximately for 20-25 minutes were carried out with 3 students in English and they were recorded basing on the consent given by the participants. Table 3 demonstrates data collection instruments and data analysis organized by research questions.

Table 3. Data collection instruments and data analysis organized by research questions

\begin{tabular}{llll}
\hline Research Questions & $\begin{array}{l}\text { Data Collection } \\
\text { Instrument }\end{array}$ & Data Analysis \\
\hline 1) & $\begin{array}{l}\text { What are the perceptions of students related } \\
\text { to EMI and IP? }\end{array}$ & $\begin{array}{l}\text { 1. QSPEMI } \\
\text { 2. Interview }\end{array}$ & $\begin{array}{l}\text { 1. Descriptive statistics } \\
\text { 2. Analysis of interview }\end{array}$ \\
2) & $\begin{array}{l}\text { Is there a relationship between the } \\
\text { perceptions of students related to EMI and }\end{array}$ & 1. QSPEMI & 1. Descriptive statistics \\
IP? & $\begin{array}{l}\text { 2. Pearson's correlation } \\
\text { 3) } \begin{array}{l}\text { Is there any significant difference between } \\
\text { female and male students in terms of the } \\
\text { perceptions concerning EMI and IP? }\end{array}\end{array}$ & $\begin{array}{l}\text { 1. QSPEMI } \\
\text { 1. Descriptive statistics }\end{array}$
\end{tabular}

\section{Results and Discussion}

\subsection{Quantitative Data Findings}

In this part of the study, the research questions are answered in the light of the findings.

RQ1: What are the perceptions of students related to EMI and IP?

A descriptive analysis was carried out to detect ELT students' perceptions with regard to EMI and IP. The most and least stated perceptions related to EMI obtained from the questionnaire are shown in Table 4.

Table 4. Perceptions of ELT students related to EMI on item basis $(\mathrm{N}=58)$

\begin{tabular}{lcclcc}
\hline \multicolumn{1}{c}{ The most stated perceptions } & Mean & $\begin{array}{l}\text { Std. } \\
\text { Deviation }\end{array}$ & The least stated perceptions & Mean & $\begin{array}{l}\text { Std. } \\
\text { Deviation }\end{array}$ \\
\hline $\begin{array}{l}\text { The EMI courses help to } \\
\text { improve my English listening } \\
\text { and speaking ability. }\end{array}$ & 4.33 & .825 & $\begin{array}{l}\text { The performance of my } \\
\text { classmates makes me } \\
\text { nervous. }\end{array}$ & 2.05 & 1.083 \\
$\begin{array}{l}\text { I like to interact with students } \\
\text { of different nationalities in } \\
\text { the EMI courses. }\end{array}$ & 4.29 & .749 & $\begin{array}{l}\text { The major difficulty I } \\
\text { encounter in EMI courses is } \\
\text { my low English proficiency. }\end{array}$ & 2.28 & 1.211 \\
$\begin{array}{l}\text { As a whole, EMI courses are } \\
\text { helpful for me. }\end{array}$ & 4.24 & .904 & $\begin{array}{l}\text { Low English proficiency } \\
\text { hinders my learning of } \\
\text { professional knowledge in } \\
\text { EMI courses. }\end{array}$ & 2.41 & 1.185 \\
\hline
\end{tabular}


According to the findings, Table 4 presents that the highest mean scores are of 3 items 'The EMI courses help to improve my English listening and speaking ability', 'I like to interact with students of different nationalities in the EMI courses', and 'As a whole, EMI courses are helpful for me' $(M=4.33$, $4.29,4.24$, respectively). The lowest mean scores of 3 items 'The performance of my classmates makes me nervous', 'The major difficulty I encounter in EMI courses is my low English proficiency', and 'Low English proficiency hinders my learning of professional knowledge in EMI courses' are also given ( $M$ $=2.05,2.28,2.41$, respectively). It can be inferred that students are satisfied with EMI courses and they benefit from the courses while improving their language skills and interacting with international students. Additionally, the students do not think they have a low level of proficiency, which shows the students have a self-confidence related to the usage of English.

Table 5 demonstrates the most and least stated perceptions obtained from the questionnaire with regard to IP of students.

Table 5. Perceptions of ELT students related to IP on item basis $(\mathrm{N}=58)$

\begin{tabular}{lcclcc}
\hline The most stated perceptions & Mean & $\begin{array}{l}\text { Std. } \\
\text { Deviation }\end{array}$ & The least stated perceptions & Mean & $\begin{array}{l}\text { Std. } \\
\text { Deviation }\end{array}$ \\
\hline $\begin{array}{l}\text { I would talk to an } \\
\text { international student if there } \\
\text { was one at school. }\end{array}$ & 4.28 & .744 & $\begin{array}{l}\text { I would feel somewhat } \\
\text { uncomfortable if a foreigner } \\
\text { moved in next door. }\end{array}$ & 1.57 & 1.045 \\
$\begin{array}{l}\text { I have thoughts that I want } \\
\text { to share with people from } \\
\text { other parts of the world. }\end{array}$ & 4.12 & .774 & $\begin{array}{l}\text { I try to avoid talking with } \\
\text { foreigners if I can. }\end{array}$ & 1.69 & .959 \\
$\begin{array}{l}\text { I want to participate in a } \\
\text { volunteer activity to help } \\
\text { foreigners living in the } \\
\text { surrounding community. }\end{array}$ & 4.07 & 1.006 & $\begin{array}{l}\text { I have no clear opinions } \\
\text { about international issues. }\end{array}$ & 2.09 & 1.031 \\
\hline
\end{tabular}

The findings in Table 5 shows that the highest mean scores are of 3 items 'I would talk to an international student if there was one at school', 'I have thoughts that I want to share with people from other parts of the world' and 'I want to participate in a volunteer activity to help foreigners living in the surrounding community' ( $M=4.28,4.12,4.07$, respectively). The lowest mean scores of 3 items 'I would feel somewhat uncomfortable if a foreigner moved in next door', 'I try to avoid talking with foreigners if I can', and I have no clear opinions about international issues' $(M=1.57,1.69,2.09$, respectively). It can be concluded that the attitudes of students towards international community is positive. The students seem to be comfortable while interacting with foreigners and they do not avoid communicating with them. In contrast, the students assert that they have clear thoughts and opinions related to international issues that they can share with foreigners.

RQ2: Is there a relationship between the perceptions of students related to EMI and IP?

A Pearson's correlation was run to determine the relationship between perceptions related to EMI and IP of novice teachers. A weak, negative correlation was found between them, which is not statistically significant $(r(58)=-.043, p=.746)$. It can be inferred that the perceptions of students related to EMI and IP do not have an impact on each other. 
RQ3: Is there any significant difference between female and male students in terms of the perceptions concerning EMI and IP?

Mann Whitney U test result of male and female students' perceptions related to EMI and IP was given in Table 6 . The results of the test indicated that there is not a significant difference in perceptions of male and female students ( $p=.962, U=393.000)$ in terms of EMI. Similarly, a significant difference was not found between male and female students in terms of IP ( $p=.138, U=303.500)$. It can be concluded that both male and female students hold similar perceptions concerning EMI and IP.

Table 6. Mann Whitney U test result of male and female students' perceptions related to EMI and IP

\begin{tabular}{|c|c|c|c|c|c|c|}
\hline & Gender & $\mathrm{N}$ & Mean Rank & Sum of Ranks & $\mathrm{U}$ & $\mathrm{p}$ \\
\hline \multirow{4}{*}{ EMI } & Male & 22 & 29.36 & 646.00 & \multirow{3}{*}{393.000} & \multirow{3}{*}{.962} \\
\hline & & & & & & \\
\hline & Female & 36 & 29.58 & 1065.00 & & \\
\hline & Male & 22 & 25.30 & 556.50 & \multirow[b]{2}{*}{303.500} & \multirow[b]{2}{*}{.138} \\
\hline Posture & Female & 36 & 32.07 & 1154.50 & & \\
\hline
\end{tabular}

\subsection{Qualitative Data Findings}

This study endeavours to examine the perceptions of students related to EMI and IP. With this aim in mind, the related questions to EMI and IP were asked to three students. The content analysis of the interviews are shown in Table 7.

Table 7. Content analysis of the interviews

\begin{tabular}{|c|c|c|c|}
\hline & $1^{\text {st }}$ student & $2^{\text {nd }}$ students & $3^{\text {rd }}$ student \\
\hline Benefits of EMI courses & $\begin{array}{l}\text { Beneficial for teaching } \\
\text { ability and skills }\end{array}$ & $\begin{array}{l}\text { Beneficial for using } \\
\text { English }\end{array}$ & Beneficial for 4 skills \\
\hline $\begin{array}{l}\text { Suggestions for EMI } \\
\text { courses }\end{array}$ & Practicing teaching skills & $\begin{array}{l}\text { Interaction between } \\
\text { students }\end{array}$ & Willingness of students \\
\hline International Posture & $\begin{array}{l}\text { Interest in } \\
\text { communicating with } \\
\text { foreigners }\end{array}$ & $\begin{array}{l}\text { Interest in international } \\
\text { issues }\end{array}$ & $\begin{array}{l}\text { Interest in international } \\
\text { issues }\end{array}$ \\
\hline
\end{tabular}

According to the first student, 'EMI courses are beneficial for improving our teaching ability. I can also say that they are helpful for our skills such as speaking and listening because we don't have any chance to practice the language outside of the class.' The second student supported this idea by stating 'I think, it is the best way to improve our English because most of us don't have an opportunity to go abroad, so we can communicate and interact with others in English in our classes.' while the third student said that 'EMI course are helpful and necessary for 4 main skills'.

To give a suggestion for EMI courses, $1^{\text {st }}$ student indicated that 'students should be made to practice their teaching skills more to be a reflective teachers in the class and be ready for the real life teaching', additionally, the $2^{\text {nd }}$ student reflected that 'speaking must be the main focus in the lessons; interaction between students should be fostered instead of the interaction between teacher and student' and the $3^{\text {rd }}$ student stated that 'Compulsory education shouldn't include EMI courses, the students should take them willingly to be more effective'. 
The students also talked about their thoughts regarding international people and issues. The $1^{\text {st }}$ student depicted that 'I like meeting and talking with international people. I already have many friends from different countries which is a great experience. The international issues interest our country and our daily life, so they are important to me. I try to discuss with foreigners and learn more about them, which helps me get a better view on the issue'. While $2^{\text {nd }}$ student mentioned 'I am interested in international people and things because learning about new things about places and people draws my attention. In this way, we can also improve our English' and the $3^{\text {rd }}$ student said that 'I am interested in international issues. I watch news, read newspapers, so I try to develop my intercultural competence'. As it can be inferred, all participants reported positive statements related to EMI courses and they have also positive international posture by stating their interest in the international issues and communication with the foreigners, which support the quantitative findings of the current study.

\section{Conclusions}

It is an inevitable fact that English is vital in today's World. "The English language is continuing to establish itself as a global lingua franca in a period of unprecedented globalisation" (Marsh, 2006, p. 29). According to Yashima (2009), the content of English lessons is going to enable students to take a global outlook, improves critical thinking with multiple perspectives since the main of L2 learning is to encourage learners to deal with an increasingly more complex globalizing world. Globalization is already the cause of extending of EMI courses throughout the World. The literature review shows several studies that support the positive effects of EMI courses (Wu, 2006; Rahmadi, 2016). Therefore, this study aimed at investigating the students' perceptions related to the usage of English in the classes and students' International Posture. In the current study, positive attitudes and perceptions of the students show that EMI courses should be given in order to foster learning language and improve language skills as the students depicted. In order to foster students' International Posture, the curriculums should be adapted by increasing student self-confidence, and awareness towards international communities and cultures. In doing so, EMI teachers should reduce the anxiety level of students by using effective strategies to facilitate understanding of students and to motivate them. Interaction with foreigners and exposing to international issues should be fostered. EMI courses should be seen an opportunity to develop the English language proficiency of undergraduate students $(\mathrm{Wu}$, 2006). The findings of the study may help educators to get new insights into adopt the best and suitable classroom-language policy and shed more light on the importance of students' posture towards an international community.

\section{References}

Aliakbari, M., Kamangar, M., \& Khany, R. (2016). Willingness to Communicate in English among Iranian EFL Students. English Language Teaching, 9(5), 33.

Asmal1, M. (2016). Willingness to Communicate of Foreign Language Learners in Turkish Context. Procedia-Social and Behavioral Sciences, 232, 188-195.

Aubrey, S. C. (2010). Influences on Japanese students' willingness to communicate across three different sized EFL classes (Doctoral dissertation, The University of Auckland).

Başıbek, N., Dolmacı, M., Cengiz, B. C., Bür, B., Dilek, Y., \& Kara, B. (2014). Lecturers’ perceptions of English medium instruction at engineering departments of higher education: A study on partial 
English medium instruction at some state universities in Turkey. Procedia-Social and Behavioral Sciences, 116, 1819-1825.

Binbaşığlu, H \& Sad, S. N. (2016). Turkish Tourism Student's International Posture. MIRDEC Conference on Social, Economic, Business and Educational Science, Budapest, HUNGARY, 2426 May.

Channa, M. A. (2012). Teachers' perceptions towards English language as a medium of instructions in Pakistan. Interdisciplinary Journal of Contemporary Research in Business, 4(5), 759-764.

Civan, A., \& Coşkun, A. (2016). The Effect of the Medium of Instruction Language on the Academic Success of University Students. Educational Sciences: Theory \& Practice, 16(6).

Collins, J. B. (2013). Willingness to Communicate and International Posture in the L2 classroom: An exploratory study into the predictive value of Willingness to Communicate (WTC) and International Posture questionnaires, and the situational factors that influence WTC. Polyglossia: the Asia-Pacific's voice in language and language teaching, 25, 61-81.

Corrales, K. A., Rey, L. A. P., \& Escamilla, N. S. (2016). Is EMI enough? Perceptions from university professors and students. Latin American Journal of Content \& Language Integrated Learning, 9(2).

Courtney, M. G. R. (2008). International posture, L2 motivation, and L2 proficiency among South Korean tertiary EFL learners (Doctoral dissertation, The University of Waikato).

Dafouz, E., \& Camacho-Miñano, M. M. (2016). Exploring the impact of English-mediuminstruction on university student academic achievement: The case of accounting. English for Specific Purposes, 44, 57-67.

Dearden, J. (2014). English as a medium of instruction-a growing global phenomenon. British Council. Online:http://www.britishcouncil.org/education/ihe/knowledge-centre/english-languagehigher-education/report-english-medium-instruction (accessed 2/2/2016).

Dorasamy, R.S (2012). The impact of English as medium of instruction on the academic performance of second language learners in the further education and training band at schools in KwaZulu-Natal (Unpublished Doctoral thesis. Durban: Durban University of technology).

Elwood, J. A., \& Monoi, N. (2015). Measuring Carefully: Validating the International PostureChild Instrument. JALT journal: the research journal of the Japan Association for Language Teaching, 37(2), 119-146.

Fallah, N., \& Mashhady, H. (2014). Testing a model of L2 communication among Iranian EFL learners: A path analysis framework, Applied Research on English Language, (4), 59-77.

Gardner, R.C. (1985). Social psychology and second language learning: The role of attitudes and motivation. London: Arnold.

Hashimoto, Y. (2002). Motivation and willingness to communicate as predictors of reported L2 use: The Japanese ESL context. University of Hawai'I Second Langauge Studies Paper 20 (2), 29-70.

Hellekjaer, G. O. (2010). Assessing lecture comprehension in Norwegian English-medium higher education. Language use and language learning in CLIL classrooms, 7, 233.

Hengsadeekul, C., Hengsadeekul, T., Koul, R., \& Kaewkuekool, S. (2010). English as a medium of instruction in Thai universities: A review of literature. In Selected Topics in Education and Education Technology: Proceedings from the 9th WSEAS International Conference on Education and Educational Technology (pp. 89-94). 
Hilliard, A. (2015). Tanzanian Students' Attitudes Toward English. TESOL Journal, 6(2), 252-280.

Huang, D. F. (2015). Exploring and assessing effectiveness of English medium instruction 71-78.

Ismail, W. R., Mustafa, Z., Muda, N., Abidin, N. Z., Isa, Z., Zakaria, A. M. \& Rafee, N. M. (2011). Students' inclination towards English language as medium of instruction in the teaching of science and mathematics. Procedia-Social and Behavioral Sciences, 18, 353-360.

Jensen, C., \& Thøgersen, J. (2011). Danish university lecturers' attitudes towards English as the medium of instruction. Ibérica, 22(22), 13-33.

Khan, H. I. (2013). An investigation of two universities' postgraduate students and their teachers' perceptions of policy and practice of English medium of instruction (EMI) in Pakistani universities (Doctoral dissertation, University of Glasgow).

Kim, J. Y. (2014). College EFL learners' speaking motivation under English-medium instruction policy. Journal of Asia TEFL, 11 (1), pp.37-64.

Kim, E. G., Kweon, S. O., \& Kim, J. (2017). Korean engineering students' perceptions of English-medium instruction (EMI) and L1 use in EMI classes. Journal of Multilingual and Multicultural Development, 38(2), 130-145.

Kirkpatrick, A. (2011). Internationalization or Englishization: Medium of instruction in todays' universities. (Working Paper Series No. 2011/003). Hong Kong: Centre for Governance and Citizenship. Hong Kong Institute of Education.

Kırkgöz, Y. (2014). Students' perceptions of English language versus Turkish language used as the medium of instruction in higher education in Turkey. Turkish Studies- International Periodical for The Languages, Literature and History of Turkish or Turkic, 9(12), 443-459.

Kym, I., \& Kym, M. H. (2014). Students' perceptions of EMI in higher education in Korea. The Journal of Asia TEFL, 11(2), 35-61.

Lauri, M. (2011). Triangulation of data analysis techniques. Papers on Social Representations, 20, 34.1-34.15.

Macnee, C. L., \& McCabe, S. (2008). Understanding nursing research: Using research in evidencebased practice. Lippincott Williams \& Wilkins.

Mahmoodi, N., Ghafoori, N., \& Amini, D. (2013). Exploring the Relationship between International Posture and Willingness to Communicate in Iranian EFL context. Life Science Journal, 10(6s).

Marsh, D. (2006). English as medium of instruction in the new global linguistic order: Global characteristics, local consequences. Finland: UNICOM, Continuing Education Centre, University of Jyva“skyla“.http://www.metsmac.org./2007/proceedings/2006/Marsh- DMETSMaC2006.pdf (accessed July 9, 2010)

Mlay, N. (2010). The Influence of the Language of Instruction on Students'Academic Performance in Secondary Schools: A comparative study of urban and rural schools in (Doctoral dissertation, University of Oslo).

Munhall, P. L., \& Oiler, C. (2001). Language and nursing research. PL Munhall (Ed.), Nursing research: A qualitative perspective, 3-35. 
Mystkowska-Wiertelak, A., \& Pietrzykowska, A. (2011). L2 willingness to communicate (WTC) and international posture in the Polish educational context. Studies in Second Language Learning and Teaching, 1(1), 119-134.

Nishida, R. (2013). The L2 Self, Motivation, International Posture, Willingness to Communicate and Can-Do among Japanese University Learners of English. Language Education \& Technology, (50), 43-67.

Nunan, D \& Bailey, K. M. (2009). Exploring Second Langauge Classroom Research: A Comprehensive Guide, Heinle ELT.

Öz, H., Demirezen, M., \& Pourfeiz, J. (2015). Willingness to communicate of EFL learners in Turkish context. Learning and Individual Differences, 37, 269-275.

Peng, J. E. (2007). Willingness to communicate in an L2 and integrative motivation among college students in an intensive English language program in China. University of Sydney Papers in TESOL, 2(1), 33-59.

Piggin, G. (2010). A case study of how international posture affects Japanese EFL learners' willingness to communicate. 文教大学国際学部紀要, 21(1), 1-14.

Rahmadani, D. (2016). Students' Perception of English as a Medium of Instruction (EMI) in English Classroom. Journal on English as a Foreign Language, 6(2), 131-144.

Saegert, J., Scott, S., Perkins, J., \& Tucker, G. R. (1974). A note on the relationship between English proficiency, years of language study and medium of instruction. Language Learning, 24(1), 99-104.

Shahzad, M. N., Sajjad, S., Ahmed, M. A., \& Asghar, Z. (2013). The role of "radical change" in medium of instruction and its impact on learning. Journal of Language Teaching and Research, 4(1), 36-44.

Siridetkoon, P. (2015). Motivation, anxiety and international posture of multiple language learners in Thailand (Doctoral dissertation, Birkbeck, University of London).

Su, Y. C. (2006). EFL teachers' perceptions of English language policy at the elementary level in Taiwan. Educational Studies, 32(3), 265-283.

Şener, S. (2014). Willingness to communicate in English as a foreign language among ELT students in Turkey (Unpublished Doctoral Dissertation, Çanakkale: Çanakkale Onsekiz Mart University).

Tilahun, A. (2015) Subject Teachers' Perceptions towards the use of English as a Medium of Instruction to Improve Students' Language Proficiency. International Journal on Studies in English Language and Literature (IJSELL),3 (9), 18-25.

Tsui, A. P. Y., \& Ngo, H. Y. (2017). Students' perceptions of English-medium instruction in a Hong Konguniversity. Asian Englishes, 19(1), 57-78.

Ulu, G., Weiwei, F., \& Yu, S. (2015). Study of the Relationship between Chinese College Students' International Posture and Their Intercultural Willingness to Communicate. Chinese Studies, 4(03), 77.

Visconde, C. J. (2006). Attitudes of Student Teachers towards the use of English as Language of Instruction for Science and Mathematics in the Philippines. Editors: Paul Robertson and Joseph Jung, 1(3), 7. 
Yashima, T. (2002). Willingness to communicate in a second language: The Japanese EFL context. The Modern Language Journal, 86(1), 54-66.

Yashima, T., Zenuk-Nishide, L. and Shimizu, K. (2004).The influence of attitudes and effect on willingness to communicate and second language communication. Language Learning 54, 119152.

Yashima, T. (2009). International posture and the ideal L2 self in the Japanese EFL context. Motivation, language identity and the L2 self, 144-163.

Zare-ee, A., \& Gholami, K. (2013). Academic justifications for preferring English as a medium of instruction by Iranian university teachers. Proceedings of the global summit on education, 426431 .

Wisdom, J. \& Creswell, JW. (2013) Mixed Methods: Integrating Quantitative and Qualitative Data Collection and Analysis While Studying Patient-Centered Medical Home Models. Rockville, MD: Agency for Healthcare Research and Quality. AHRQ Publication.13-0028-EF.

Wu, W. S. (2006). Students' attitudes toward EMI: Using Chung Hua University as an example. Journal of Education and Foreign Language and Literature, 4, 67-84.

\section{Öğrencilerin bakış açısına göre eğitim dili olarak İngilizce ve enternasyonal tutum}

\section{$\ddot{O} z$}

Eğitim süresince aktif rol oynadıkları için, ögrenci algılarının eğitim alanına önemli bir etkisi vardır. Bu bağlamda, öğrencilerin algılarını ortaya çıkarmak, öğrenme ve öğretmedeki gelişmelere katkıda bulunmaktadır. Bu çalışmanın amacı bir devlet üniversitesinde okuyan İngiliz Dili Eğitimi bölümü öğrencilerinin enternasyonal tutumlarını ve eğitim dili olarak İngilizce kullanımıyla ilgili algılarını incelemektir. Ek olarak, bu çalışma öğrencilerin algı ve tutumları arasında cinsiyete bağlı farklılık olup olmadığını bulmayı amaçlamaktadır. Araştırma 2016-2017 bahar yarıyılında Çanakkale Onsekiz Mart Üniversitesi İngiliz Dili Eğitimi bölümü öğrencileri ile yapılmıştır. Anket ve yarı yapılandırılmış görüşmeler öğrencilerin enternasyonal tutumları ve öğretim dili olarak İngilizce kullanımı hakkındaki algılarının birbiriyle ilişkili olup olmadığını saptamak üzere kullanılmıştır. Anket aracilığılla elde edilen nicel veriler SPSS kullanılarak betimleyici istatistikler, Pearson korelasyonu ve Mann Whitney U testi ile analiz edilirken nitel veriler için içerik analizi yapılmıştır. Mevcut çalışma cinsiyet farklılıklarının yanı sıra, İngiliz Dili Eğitimi öğrencilerinin İngilizceyi eğitim dili olarak kullanma hakkındaki algılarını ve enternasyonal tutumları arasındaki ilişkiyi de gözler önüne sermiştir. Bulgulara göre, yüksek enternasyonal tutuma sahip öğrenciler İngilizceyi eğitim dile olarak kullanmaya pozitif yaklaşmışlardır. Fakat, bu iki konu arasında önemli derecede bir korelasyon bulunmamıştır. Araştırmanın sonuçları ileride yapılacak çalışmalar için öneriler sunmaktadır.

Anahtar sözcükler: İngiliz dili eğitimi; öğrenci algısı; eğitim dili olarak İngilizce; enternasyonal tutum; bakış açısı 


\section{AUTHOR BIODATA}

Dinçay Köksal graduated from ELT Department of Faculty of Education at Ondokuz Mayıs University in Samsun in 1984 and worked as teacher in secondary schools for 3 years. Then he started his M.A in Gazi University in 1987 and completed it in 1990. He finished his doctoral study in the same university in 1994. He also worked as lecturer in ELT department of Gazi faculty of Education for seven years and gave Advanced Translation courses in the Turkish Military Academy. He worked as an instructor and assistant professor in Abant İzzet Baysal University for eighteen months. In December 1995 he started to work in Çanakkale Onsekiz Mart University. Since then, he has been teaching such courses as 'Translation', 'Testing and Evaluation in English Language Education', 'Teaching English/Foreign Language to Young Learners' in B.A and M.A programmes 'Philosophy of Educational Research' in PhD programme. He founded Foreign Language Education Research and Practice Center in that university in 1996. He organised many international conferences - International ELT Research Conferences. He also founded some associations - NGOs concerning language education and education research in general - UDEAD, ULEAD and EAB (Educational Research Association) in Turkey in 2008. He coordinated one EU lingua project locally as a partner called 'European Awareness and Intercomprehension'. He is now a local coordinator of another project called 'Redinter'. He has many articles published in journals and papers presented at international conferences and congresses. He is the author of a book on teaching translation, and co-author of a book on Intercultural Communication and the editor of two books.

Gülşah Tercan graduated from ELT Department at Gazi University in 2013. She received her MA degree in ELT from Çanakkale Onsekiz Mart University in 2015. She also started her teaching career at the same university in 2013. She is currently working as an instructor at the School of Foreign Languages at Pamukkale University. She is also a PhD candidate studied at Çanakkale Onsekiz Mart University. During her work experience, she attended several ELT workshops and conferences. Her main research areas of interest are Teacher Research, Professional Development and Program Evaluation. 